Original scientific article/Izvirni znanstveni članek

\title{
Organizational culture in general hospitals and its relationship with job satisfaction

\author{
Organizacijska kultura $\mathrm{v}$ splošnih bolnišnicah in njena povezanost $\mathrm{z}$ zadovoljstvom \\ zaposlenih
}

\author{
Katja Skinder Savić, Brigita Skela-Savič
}

Key words: leadership; decision-making; collaboration between nurses and physicians; hierarchy; teamwork

Ključne besede: vodenje; odločanje; medpoklicno sodelovanje medicinske sestre in zdravniki; hierarhija; timsko delo

pred. mag. Katja Skinder Savić, viš. med. ses., univ. dipl. org.

Correspondence e-mail/

Kontaktni e-naslov:

kskindersavic@vszn-je.si

izr. prof. dr. Brigita SkelaSavič, viš. med. ses., univ. dipl. org.

Both/Obe: Fakulteta za zdravstvo Jesenice, Spodnji Plavž 3, 4270 Jesenice

The article is based on the MA thesis Katja Skinder Savić Organizational culture in general hospitals and its correlation to job satisfaction/Organizacijska kultura v splošnih bolnišnicah in njena povezanost $z$ zadovoljstvom zaposlenih (2013).

Received/Prejeto: 12. 4. 2014

Accepted/Sprejet/: 27. 5. 2014

\section{ABSTRACT}

Introduction: Organizational culture is formed via communication, resolving conflicts, team work and interconnection. The aim of the study was to present the connections between organizational culture and job satisfaction indicators.

Methods: A quantitative descriptive approach was used. The study included nursing employees and medical practitioners in six Slovenian hospitals. A 30 per cent quota sample was used, with a response rate of $35.2 \%(n=310)$. The Organization Culture Assessment Instrument (OCAI) $(\alpha=0,818)$ and Index of Work Satisfaction $(\alpha=0,921)$ questionnaires were used. The data was processed with SPSS 20.0 statistical software by using the $t$-test, single variance analysis, correlation, factor and regression analysis.

Results: The greatest total average value among employees of both job groups with regard to organizational culture was the market $(\overline{\mathrm{X}}=28.21)$ and hierarchy $(\overline{\mathrm{X}}=27.57)$. Job satisfaction indicators (collaboration, leadership, decision-making, autonomy) can be explained in $20 \%$ of cases with adhocracy organizational culture $(\beta=0.318, p<0.001)$, market $(\beta=0.219, p<0.001)$ and $\operatorname{clan}(\beta=0.161, p=0.006)$.

Discussion and conclusion: In Slovenian hospitals, control over work, abiding by the rules and attaining, goals prevails. An overview of the literature reveals the influence of culture on satisfaction. Other factors affecting satisfaction, including stress and abuse of hierarchical power, should be studied.

\section{IZVLEČEK}

Uvod: Organizacijska kultura se oblikuje skozi komuniciranje, reševanje konfliktov, timsko delo in medsebojno povezovanje. Namen raziskave je bil prikazati povezavo organizacijske kulture z indikatorji zadovoljstva zaposlenih.

Metode: Uporabljen je bil kvantitativni opisni pristop. V raziskavo so bili vključeni zaposleni v zdravstveni negi in medicini v šestih slovenskih bolnišnicah. Oblikovan je bil $30 \%$ kvotni vzorec, odzivnost je bila 35,2 \% $(n=310)$. Uporabljena sta bila vprašalnika Organization Culture Assessment Instrument (OCAI) $(\alpha=0,818)$ in Index of Work Satisfaction $(\alpha=0,921)$. Podatki so bili obdelani s statističnim programom SPSS $20.0 \mathrm{z}$ uporabo $t$-testa, enosmerne analize variance, korelacijske, faktorske in regresijske analize.

Rezultati: Skupna največja povprečna vrednost med zaposlenimi obeh poklicnih skupin je pri organizacijski kulturi trg $(\overline{\mathrm{X}}=28,21)$ in hierarhija $(\overline{\mathrm{X}}=27,57)$. Indikatorji zadovoljstva zaposlenih (sodelovanje, vodenje, odločanje, avtonomija) se v $20 \%$ lahko pojasnijo z organizacijsko kulturo adhokracija $(\beta=0,318, p<0,001), \operatorname{trg}(\beta=0,219, p<0,001)$ in skupina $(\beta=0,161, p=0,006)$.

Diskusija in zaključek: V slovenskih bolnišnicah prevladuje nadzor nad delom, upoštevanje pravil, doseganje ciljev. Pregled literature pokaže tudi vpliv organizacijske kulture na zadovoljstvo. Potrebno bi bilo raziskati še druge dejavnike, ki vplivajo na zadovoljstvo, kot sta stres, izkoriščanje moči položaja. 


\section{Introduction}

Schein (1999) argues that a certain type of organizational culture is always prevalent in an organization, depending on how the organization's employees communicate, resolve conflicts, work as a team and connect among themselves. An organizational culture that supports safe and highquality patient care must be promoted (Alexander, et al., 2006; Alexander, et al., 2007; Reyes-Alcázar, et al., 2009; Ledderer, 2010). To this end, organizational culture building blocks, including leadership, team work, evidence-based practice and communication should be used (Sammer, et al., 2010). A crosssectional study revealed that organizational culture is typically related to the behaviour of its leaders, which is statistically typically related to satisfaction (Tsai, 2011). According to a study based on a randomised sample of nurses, $20 \%$ of satisfaction can be accounted for by authentic leadership (Giallonardo, et al., 2010). According to findings based on interviews conducted in a Canadian hospital, nurses do not have the opportunity to participate in the decision-making process and introducing change. Nurses said that they were not part of the research process, whereas evidence-based nursing was promoted during their studies (Scott \& Pollock, 2008). A survey conducted among 749 employees with different job profiles in hospitals in Greece revealed hierarchical organisation and a desire for more team work (Bellou, 2007). Bosch, et al. (2011) conducted a cross-sectional study among 460 health workers in 37 hospital wards and 67 wards in nursing homes. It was established that hierarchical organization culture prevails in the hospital, followed by clan culture, while clan culture prevails in the nursing home, followed by hierarchy. The least amount of market culture and adhocracy was found in both hospitals and nursing homes. In the USA, it has been established that job satisfaction indicators can be explained by organizational culture. Clan culture was assessed to have a statistically positive link, while hierarchic and market cultures were associated with a statistically negative link, while adhocracy had no statistically typical relation to satisfaction indicators. Among physicians, clan culture was prevalent, followed by market, hierarchy and adhocracy (Zazzali, et al., 2007). The American Nurses Association (ANA) established a database of nursing quality indicators, one of which is job satisfaction. Job satisfaction is a major factor that statistically typically affects job fluctuation and absenteeism and the quality of health care provided to patients (Taunton, et al., 2004). Depending on the motives of individuals, the motivation theories of Maslow and Herzberg (Zangaro \& Soeken, 2005) form the bases for determining satisfaction indicators. In four Slovenian hospitals, Lorber and Skela Savič (2012) identified 4 common job satisfaction indicators among nurses, i.e. motivation, leadership method, professional development, cooperation and interpersonal relationships. While professional development is not directly connected to satisfaction, it is statistically typically positively related to nurses' autonomy, which, in turn, affects job satisfaction (Cummings, et al., 2008). Autonomy, job position, interpersonal relations and pay account for $50 \%$ of variation regarding job satisfaction (Taunton, et al., 2004). Stress and work burnout, and shift work have a statistically negative correlation to satisfaction indicators of nurses (Kawada \& Otsuka, 2011). Among physicians, the following satisfaction indicators were identified: autonomy, interpersonal relations among employees, relationship with patients, job position, pay, personal income (Williams, et al., 2007).

\section{Purpose and goal}

The purpose of the study was to present the typical features of organization culture in general hospitals in Slovenia and job satisfaction indicators among nursing employees and medical practitioners.

The goal of the study was to research types of organizational culture in general hospitals and to compare the findings with those of other studies conducted in Slovenia and elsewhere around the world. We also wanted to verify the model of explanation for job satisfaction.

\section{Hypothesis}

H1: Respondents with higher qualifications assess the presence of clan and adhocracy organizational culture to greater numbers than respondents with lower level of qualifications.

$\mathrm{H} 2$ : Job satisfaction indicators in nursing and medicine can be explained by collaboration in the team, and decision-making and leadership styles.

H3: Adhocracy organizational culture is statistically positively correlated to satisfaction indicators.

\section{Methods}

Quantitative research approach, a descriptive working method was used in carrying out the research.

\section{Description of the instrument}

The questionnaire consisted of two sets of content, i.e. organizational culture in health care and job satisfaction at work. We used two questionnaires that had already been tested for both in health care organizations. At the beginning of the questionnaire, we asked for demographic information, i.e. general information (age, gender, work experience in nursing/medicine), the employee's position at work, level of education and working area (medicine/ nursing). To assess organizational culture, we used 
the Organizational Culture Assessment Instrument (OCAI) questionnaire developed by Cameron and Quinn (1999), who recognised four types of organizational culture: hierarchy, clan, market and adhocracy. Organizational cultures of hierarchy and clan are inward-oriented, while market and adhocracy organizational cultures are outward oriented. A stable environment and centralised decision-making is typical of hierarchy and market organizational culture. The authors state that clan organisation culture was already typical of Japanese companies between 1960 and 1970. Employees share values and goals, while the main characteristics are not rules, but cohesion, dedication and encouraging professional development. For an adhocracy organizational culture, a dynamic and creative working environment is typical. The instrument assesses six crucial aspects of organizational culture: dominant characteristics, organizational leadership, management of employees, statements from the questionnaire, translated them into Slovene and used a 5-point Likert's scale, with 1 indicating that the respondents completely disagreed with the statement, while 5 indicated that the respondents completely agreed with the statement, and intermediate marks corresponded to the scale of values. The instrument's reliability coefficient Cronbach's coefficient was 0.921 .

\section{Sample description}

We conducted the study in 6 general hospitals in Slovenia, which consented to participation, among nursing employees and medical practitioners. We used non-coincident, quota sample. We opted for 30 $\%$ sample of respondents (Table 1). We distributed a somewhat greater share of questionnaire among medical practitioners, as we had anticipated lesser response than among nursing employees.

Table 1: Sample structure

Tabela 1: Struktura vzorca

\begin{tabular}{llllll}
\hline Area of work & $\begin{array}{l}\text { Number of } \\
\text { distributed } \\
\text { questionnaires }(n)\end{array}$ & $\begin{array}{l}\text { Share with regard } \\
\text { to a total number } \\
\text { of employees in } \\
\text { all participating } \\
\text { hospitals (\%) }\end{array}$ & $\begin{array}{l}\text { Number of } \\
\text { returned } \\
\text { questionnaires }(n)\end{array}$ & $\begin{array}{l}\text { Number of } \\
\text { returned } \\
\text { questionnaires } \\
(\%)\end{array}$ & $\begin{array}{l}\text { Share with } \\
\text { regard to the } \\
\text { total number } \\
\text { of employees in } \\
\text { participating } \\
\text { hospitals }(\%)\end{array}$ \\
\hline Nursing & 630 & 29.4 & 250 & 39.7 & 11.7 \\
\hline Medicine & 250 & 34.4 & 60 & 24 & 8.2 \\
\hline Total & 880 & 30.6 & 310 & 35.2 & 10.8 \\
\hline
\end{tabular}

Legend/Legenda: $n$ - number/število; \% - percentage/odstotek

organisation glue, strategic emphases, and criteria of success.

There are four questions in each set, and the test taker must split 100 points over a total of four descriptions, which represents the share of agreement with each statement. The respondents clarified their position in two time periods: the current situation and with regard to their wishes for the future. Reliability coefficient - Cronbach's alpha coefficient for all 48 statements in the questionnaire on establishing organizational culture was 0.818 . We used the questionnaire from the doctoral dissertation "Dejavniki uspešnega izvajanja sprememb v slovenskem zdravstvu " (Skela Savič, 2007). We used Index of Work Satisfaction (IWS) to study the job satisfaction indicators in the fields of medicine and nursing. IWS includes six indicators of job satisfaction, comprising 48 statements and is based on 7-point Likert's scale (Murrells, et al., 2009). The questionnaire was designed on the basis on meta-analysis and tested in numerous health care organisations in the United States of America, showing a high level of reliability with regard to establishing job satisfaction indicators in the health-care sector (Zangaro \& Soeken, 2005). In our survey, we used 37
880 questionnaires were distributed among both groups of employees and received 310 questionnaires, which presents a $35.2 \%$ response rate. We distributed 250 questionnaires to medical practitioners, and received 60 back, which presents a $24 \%$ response rate. We distributed 630 questionnaires to nursing employees, and received 250 back, which presents a $39.7 \%$ response rate. Completed questionnaires present a $10.8 \%$ sample with regard to all nursing employees and medical practitioners in participating hospitals. The average age of respondents was 38.3 years ( 37.2 for nurses and 43.2 for physicians), with an average of 16.3 years of work experience in a hospital (16.4 for nurses and 15.6 for physicians). Among the respondents, $48(15.5 \%)$ held a leading position, i.e. $30(12 \%)$ heads among the nurses and $18(30 \%)$ among physicians. Among the respondents, 58 (18.7 $\%)$ were men and $251(81 \%)$ were women, while $1(0.3 \%)$ respondent did not answer the question about sex. In both groups of employees there was a greater share of women (88 \% among nurses and $51.7 \%$ among physicians). Nurses who participated in the study had a secondary school degree (50\%), higher-education professional degree (41.2\%), while there was a smaller share of those with associate 
diploma (3.2\%), professional master's degree (3.2 $\%)$, bachelor's degree (1.2\%), or master's of science (1.2 \%). Among the participating physicians, the of science greatest number had a PhD (41.7\%), completed their specialisation studies $(26.7 \%)$ or had a university degree (25\%), while a smaller share had a research master's degree (6.6\%).

\section{Description of the process of research and data processing}

We asked the health and nursing care management in all 10 general hospitals in Slovenia to participate in the study, and 6 hospitals agreed. According to this agreement, the study was conducted between May 2012 and the end of February 2013. A cover letter stating the purpose and objectives of the study was enclosed to the questionnaire. Participation in the survey was voluntary and anonymity was guaranteed, since the data were interpreted only in a summary form. Coordination of the study was conducted via telephone and e-mail. In every general hospital, someone was delegated to be the responsible person who took care of the course of the survey, the completion and return of questionnaires by post. Respondents had 14 days to complete the questionnaires. Statistical analyses were performed with the SPSS statistical software ver. 20.00 (SPSS, Chicago, IL, USA). Independent variables (demographic data, organizational culture) were used to explain the dependent variables (indicators of employee satisfaction). We used $t$-test to assess the arithmetic mean, $t$-test for independent samples, one-way analysis of variance, correlation, regression and factor analysis. With the $t$-test for the evaluation of the arithmetic mean, we evaluated the average value of each type of organizational culture. The $t$-test for independent samples was used to determine statistically significant differences between types of organizational culture in the group of nursing employees and medical practitioners. One-way analysis of variance was used to determine statistically significant differences regarding the assessment of organizational culture considering the level of education. Correlation analysis was used to establish a statistically significant correlation between variables. We used Pearson's correlation coefficient. In continuation, we assessed the general factor model, an estimate of the proportion of the variance of the studied variables clarified with common factors (communalities) with the maximum likelihood method and Varimax orthogonal rotation. We discovered common aspects of observed variables and thus got an insight into the underlying structure of the data. With a smaller number of latent variables, called factors, we explained the relationship between the observed variables. Regression analysis was used to determine which independent variables can explain the dependent variable. We assessed the multivariate linear regression model. Statistical significance was examined at the level of $5 \%$ of the risk $(p=0.05)$.

\section{Results}

The study established that all types of organization culture according to Cameron and Quinn (1999) were present. The results are presented in Table 2.

The $t$-test for the arithmetic mean was used to establish that with regard to organizational culture the total maximum average value among both groups of employees was the market $(\overline{\mathrm{x}}=28.21)$,

Table 2: Assessment of organizational culture

Tabela 2: Ocena organizacijske kulture

\begin{tabular}{|c|c|c|c|c|c|c|c|c|}
\hline \multirow{2}{*}{$\begin{array}{l}\text { Type of organizational } \\
\text { culture }\end{array}$} & \multicolumn{2}{|l|}{ Total } & \multicolumn{2}{|c|}{ Medicine } & \multicolumn{2}{|c|}{ Nursing } & \multicolumn{2}{|c|}{$\begin{array}{l}\text { Difference between } \\
\text { the groups }\end{array}$} \\
\hline & $\bar{x}$ & $s$ & $\bar{x}$ & $s$ & $\bar{x}$ & $s$ & $F$ & $p$ \\
\hline \multirow{2}{*}{$\begin{array}{l}\text { HIERARCHY } \\
\text { today wishes } \\
\text { for the future }\end{array}$} & 27.57 & 19.56 & 19.93 & 23.28 & 29.4 & 18.13 & 1.71 & 0.191 \\
\hline & 22.63 & 21.7 & 23.41 & 32 & 22.44 & 18.46 & 18.7 & $<0.001$ \\
\hline \multirow{2}{*}{$\begin{array}{l}\text { CLAN } \\
\text { today wishes } \\
\text { for the future }\end{array}$} & 22.37 & 16.5 & 28.31 & 28.6 & 22.39 & 15.16 & 18.69 & $<0.001$ \\
\hline & 32.58 & 21.1 & 34.83 & 35.9 & 35.64 & 19.97 & 1.06 & 0.302 \\
\hline \multirow{2}{*}{$\begin{array}{l}\text { MARKET } \\
\text { today wishes } \\
\text { for the future }\end{array}$} & 28.21 & 20.43 & 25.26 & 26.53 & 28.92 & 18.67 & 10.9 & 0.001 \\
\hline & 18.03 & 18.83 & 20.58 & 28.86 & 17.42 & 15.51 & 21.44 & $<0.001$ \\
\hline \multirow{2}{*}{$\begin{array}{l}\text { ADHOCRACY } \\
\text { today wishes } \\
\text { for the future }\end{array}$} & 21.14 & 18.79 & 23.23 & 28.36 & 20.63 & 15.69 & 20.42 & $<0.001$ \\
\hline & 21.95 & 19.26 & 17.5 & 20.03 & 23.02 & 18.96 & 1.42 & 0.233 \\
\hline
\end{tabular}

Legend/Legenda: $\mathrm{X}$ - average/povprečje; $s$ - standard deviation/standardni odklon; $p$ - a statistically significant value in the 0.05 or less/statistično pomembna vrednost pri 0,05 ali manj; $F$ - difference between groups/ razlika med skupinami 
hierarchy $(\overline{\mathrm{x}}=27.57)$, clan $(\overline{\mathrm{x}}=22.37)$ and adhocracy $(\overline{\mathrm{x}}=21.14)$. With regard to desires for the future, employees desired clan organizational culture the most $(\overline{\mathrm{x}}=32.58)$, followed by hierarchy $(\overline{\mathrm{x}}=22.63)$, adhocracy $(\overline{\mathrm{x}}=21.95)$ and the market $(\overline{\mathrm{x}}=18.03)$. The $t$-test for independent samples was used to assess statistically significant differences according to employee group in determining organizational culture today, i.e. organizational culture of adhocracy $(F=20.42, p<0.001)$, clan $(F=18.69, p<0.001)$ and the market $(F=10.9, p=0.001)$. In comparison to the nurses, there was clan and adhocracy culture among physicians, while there was more market culture among the nurses. With regard to desires for the future, were assessed statistically significant differences with regard to the market organizational culture $(F=21.44, p<0.001)$ and hierarchy $(F=18.7$, $p<0.001)$. Physicians had a greater desire for both of these cultures than nurses.

The analysis of variance (One-Way ANOVA) was used to determine statistically significant differences regarding organizational culture by level of education. Individual levels of education/qualifications were combined into four categories: secondary school, first level (higher-education professional degree, associate degree), second level (university, specialisation, professional master's degree) and third level (master of science and doctorate). Based on Levine's test of equality of variances in groups (Test of Homogeneity of Variances) used the F-test or the Robust Welch test to determine if the average values differ between the groups. The results showed statistically significant differences with regard to market organizational culture by level of education $(p<0.001)$. The highest average value was assessed by employees with the first level of education $(\overline{\mathrm{x}}=28.2)$ and secondary education $(\overline{\mathrm{x}}=27.1)$, while it was slightly lower among employees with second level of education $(\bar{x}=26.5)$, and the lowest among employees with the third level of education $(\overline{\mathrm{x}}=17.44)$. We did not find statistically significant differences by level of education with regard to other types of organizational culture. Regarding desires for the future, we assessed statistically significant differences by level of education in adhocracy organizational culture $(p=0.005)$. The estimate of the average value was the highest with employees with the first level of education ( $\overline{\mathrm{x}}=25.15)$, followed by an assessment of employees with secondary education $(\overline{\mathrm{x}}=20.94)$, third level $(\overline{\mathrm{x}}=19.97)$ and second level of education $(\overline{\mathrm{x}}=18.42)$. We did not find statistically significant differences between the groups with regard to other types of organizational culture.

Pearson's correlation coefficient showed a strong statistically significant positive correlation between indicators of employee satisfaction. Strongest statistically significant positive correlation was found between respect for other occupational groups (medicine/nursing), and appreciating the work of the other group of employees $(r=0.718, p<0.001)$ as well as the opportunity to participate in the decisions of the health team and the decisions relating on the work of the employee $(r=0.626, p<0.001)$. Independent decision-making is significantly positively associated with the opportunity to take part in decision-making related to the work of the employee $(r=0.678$, $p<0.001)$ and with the opportunity to participate in the decisions of the medical team $(r=0.521, p<0.001)$. Pearson's correlation coefficient $(r>0.5)$ also showed a statistically significant positive correlation at the following links:

- support and kindness among co-workers $(r=0.548$, $p<0.001$ );

- the significance of treatment and health care for the health of the patient and appreciation for the work of the other group of employees $(r=0.558$, $p<0.001$ );

- the significance of treatment and health care for the health of the patient and respect for the work of the other group of employees $(r=0.520, p<0.001)$

- the possibility for the employee to demonstrate his/her abilities and opportunities for professional development $(r=0.506, p<0.001)$;

- cooperation with other occupational groups and satisfaction with cooperation of the same occupational group $(r=0.504, p<0.001)$;

- independent decision-making and independent planning of interventions within the scope of competences $(r=0.502, p=0.001)$.

In continuation, we present a summary of the common indicators of satisfaction. We used factor analysis to establish that the 5 common factors explained $58.7 \%$ of the variability of indicators of employee satisfaction. Good cooperation can account for $26.1 \%$, satisfaction with decision-making for $16.7 \%$, satisfaction with leadership for $10.3 \%$, stress in the workplace for $7.5 \%$, and autonomy for $6.5 \%$ of job satisfaction variation. Table 3 shows the factor weights with orthogonal rotation after Varimax under which the value of Kaiser-Meyer Olkin test was the highest (0.861), this rotation is compared with oblique rotation after Oblimin, which showed less bipolarity. Statements where the proportion of variability explained by common factors was less than 0.5 were excluded from further analysis.

Regression analysis was used to determine the dependence of indicators of satisfaction on each type of organizational culture. Factors which were identified by using factor analysis were combined into 'satisfaction indicators' dependent variable. Six statements from the questionnaire describing each type of organizational culture were combined into the independent variable 'types of organizational culture' for each type of organizational culture. We assessed the multivariate linear regression model. Independent variables were included in the Forward Selection Method regression model. In this method, 
Table 3: Varimax rotation method of job satisfaction

Tabela 3: Pravokotna rotacija faktorjev zadovoljstva zaposlenih

\begin{tabular}{|c|c|c|c|c|c|}
\hline \multirow[b]{2}{*}{ Statements } & \multicolumn{4}{|c|}{ Factors } & \multirow[b]{2}{*}{5} \\
\hline & 1 & 2 & 3 & 4 & \\
\hline Employees appreciate the work of the other group of employees. & 0.714 & I & I & I & I \\
\hline Satisfaction with the work of the other occupational group. & 0.666 & I & 1 & I & I \\
\hline Employees respect the work of the other occupational group. & 0.646 & I & 1 & I & l \\
\hline Opportunity to take part in decisions that affect the work of the employee. & I & 0.858 & 1 & I & I \\
\hline Independent decision-making within competences. & I & 0.682 & 1 & I & 1 \\
\hline Opportunity to take part in the decisions of the medical team. & I & 0.642 & I & I & I \\
\hline Employees are rewarded for good work. & I & 1 & 0.760 & 1 & I \\
\hline Employees only perform routine tasks. & I & 1 & 0.544 & 1 & I \\
\hline The head controls the work of the employees more than it is necessary. & I & 1 & 0.545 & I & I \\
\hline $\begin{array}{l}\text { The employees would be able to perform their work better if they were under } \\
\text { less stress at work. }\end{array}$ & l & l & l & 0.894 & l \\
\hline Working with documentation takes the employees a lot of time. & l & l & l & 0.471 & I \\
\hline $\begin{array}{l}\text { The employee would be able to provide higher-quality health care if they had } \\
\text { more time for each patient. }\end{array}$ & l & l & l & 0.469 & l \\
\hline $\begin{array}{l}\text { Employees have enough autonomy at their job for making independent } \\
\text { decisions about their work. }\end{array}$ & l & l & l & l & 0.736 \\
\hline The head commends employees for a job well done. & 1 & 1 & 1 & 1 & 0.513 \\
\hline
\end{tabular}

Table 4: The multivariate linear regression model for indicators of job satisfaction Tabela 4: Multivariatni linearni regresijski model za indikatorje zadovoljstva zaposlenih

\begin{tabular}{llllll}
\hline Model & $\boldsymbol{R}$ & $\boldsymbol{R}^{2}$ & Adjusted $\boldsymbol{R}^{2}$ & $\boldsymbol{F}$ & $\boldsymbol{p}$ \\
\hline Adhocracy organizational culture & 0.391 & 0.153 & 0.150 & 55.73 & $<0.001$ \\
\hline Adhocracy and market organizational culture & 0.424 & 0.180 & 0.174 & 33.64 & $<0.001$ \\
\hline Adhocracy, market and clan organizational culture & 0.447 & 0.200 & 0.192 & 25.44 & $<0.001$ \\
\hline
\end{tabular}

Legend/Legenda: $R$ - the correlation coefficient/korelacijski koeficient; $R^{2}$ - the coefficient of determination/determinacijski koeficient; popravljeni $R^{2}$-the adjusted coefficient of determination/popravljeni determinacijski koeficien/; $p$ - statistically significant at 0.05 or less/ statistična značilnost pri 0,05 ali manj

the independent variables are included in the regression model in the order determined by the size of their impact on the dependent variable. First, the independent variable that has the greatest impact on the dependent one is included, then the one with second most impact on the dependent variable, provided that the first variable is already included in the model. There are all types of organizational culture in the organization, but in different shares (Schein, 1999), so we decided to determine which combination of cultures has the strongest impact on job satisfaction. Based on a sample of physicians and nurses in Slovenian general hospital we concluded that at least one type of organizational culture has a statistically significant impact on indicators of job satisfaction at the workplace. Regression coefficients showed that the following combinations of organizational cultures have a statistically significant positive impact on the indicators of employee satisfaction:

- adhocracy organizational culture $(\beta=0.391, p<0.001)$,

- adhocracy organizational culture $(\beta=0.377, p<0.001)$ and market $(\beta=0.163, p=0.002)$,

- adhocracy organizational culture $(\beta=0.318$, $p<0.001)$, market $(\beta=0.219, p<0.001)$ and clan $(\beta=0.161, p=0.006)$.

It was established that the hierarchy organizational culture does not statistically significantly affect job satisfaction $(p=0.490)$. Table 4 presents the multivariante linear regression model for indicatiors of job satistacion.

Based on the evaluation of the correlation coefficient we established that the relationship between organizational culture and job satisfaction indicators was positive and moderately strong. When combining the three organizational cultures, i.e. adhocracy, market and clan, the correlation is the strongest $(\mathrm{R}=0.447)$. Estimated coefficient of determination showed that $15 \%$ of the variance of indicators of job satisfaction can be explained by organizational culture adhocracy, $18 \%$ of the variance satisfaction indicators with the organizational culture adhocracy and market, and $20 \%$ of the variance of satisfaction indicators can be explained by organizational culture adhocracy, market and clan.

\section{Discussion}

On the basis of sample data, the study showed 
indicatorsthatexplainjobsatisfactionamongphysicians and nurses in general hospitals in Slovenia. We studied the links between the independent and dependent variables. We have identified the following indicators of satisfaction, i.e. good cooperation, satisfaction with leadership, satisfaction with decision-making, stress at work and job autonomy, while in an Atlanta hospital indicators of satisfaction of nurses were leadership, cooperation and support of employees and manager ability (Wade et al., 2008). Wang et al. (2012) had similar findings and explained satisfaction indicators with personal income and remuneration, interprofessional cooperation, professional development, and autonomy. Correlation analysis showed weak statistically significant positive correlation between demographic factors and indicators of job satisfaction. Carmen (2005), Wade et al. (2008), Tourangeau, et al. (2010) and Pavlakis et al. (2011) have come to similar findings. In our study, we concluded that market organizational culture is the most prevalent in Slovenian general hospitals, followed by hierarchy, clan and adhocracy. There are statistically significant differences in determining the organizational culture today between the two groups of employees, specifically adhocracy, clan and market. There is more clan and adhocracy culture among physicians, while market culture is prevalent among the nurses. Golob (2006) came to similar conclusions in Novo mesto nursing home, where market culture was dominant, while at the General Hospital Celje clan culture was prevalent (Kragelj, 2010). According to nurses, market and hierarchy cultures are dominant, and clan culture was the least present, while the statement about professional development received the lowest marks (Tsai, 2011). In our study, employees were shown to have the greatest desire for clan organizational culture, followed by hierarchy, adhocracy and market. There are statistically significant differences with regard to the desired organizational culture in the future between the two groups of employees, i.e., the organizational culture of market and hierarchy. These are both desired more by physicians than nurses. In Celje general hospital (Kragelj, 2010) and a Canadian hospital (Williams et al., 2007) employees want more adhocracy culture. The age of respondents and the number of years in employment did not significantly affect the type of organizational culture, while the level of education has a statistically significant impact on the cultures of adhocracy and hierarchy (Skela Savič, 2006).

Carmen (2005) found no statistically significant correlation between demographic data and the types of organizational culture, while in Slovenian hospitals we found a weak statistically significant positive correlation between demographic factors (age, work experience, position in the workplace, education level) and organizational culture. A one-way analysis of variance revealed statistically significant differences between the levels of education only in the market organizational culture. The lowest average value of present culture in Slovenian hospitals was assessed with regard to employees with third-level education. Skela Savič (2006) found that the higher the level of education of respondents, the more they assessed the presence of culture of hierarchy and less adhocracy culture in their working environment.

With regard to nursing, it was established that the higher the education level, the less the organizational culture in their working environment is seen as innovative (Skela Savič, 2006). With regard to desires for the future, the results of our study in Slovenian general hospitals showed statistically significant differences between groups in adhocracy organizational culture. This culture is most desired by employees with the first level of education, and least by employees with second level of education. Organizational culture is significantly positively associated with indicators of employee satisfaction in the workplace, but we found that correlations were weak, Jacobs \& Roodt (2008) and Tsai (2011) came to similar conclusions. Indicators of employee satisfaction are statistically significantly positively related to clan organizational culture (Williams et al., 2007; Park \& Hyun, 2009) and market, while the culture of hierarchy and adhocracy were found to have no statistically significant links with indicators of satisfaction (Park \& Hyun, 2009). In our study, regression analysis showed that the indicators of employee satisfaction are most significantly positively affected by the presence of three types of organizational cultures, i.e. adhocracy, market and clan.

\section{Limitations of the study}

Methodological limitations of the study were that it was conducted in 6 out of 10 general hospitals. Participants included nursing employees and medical practitioners; there was lower response rate among employees in medical practitioners than with nursing employees. The study results can not be generalised because a non-random, quota sample was used, in which we cannot determine the quality of the sample estimates. We used a quantitative research approach, survey method. Schein (1999) argues that in assessing organizational culture it is necessary to use other methods of research (interviews, observation method, triangulation, etc.). The results with regard to organizational culture showed high levels of standard deviations, which signifies a lot of variability in the data, which was greater with regard to physicians than nurses. Individual statements in the questionnaire were assessed from 0 to 100 .

\section{Conclusion}

The purpose and objective of the research were achieved, indicators of job satisfaction and 
characteristics of organizational culture in general hospitals in Slovenia were assessed and compared with other research carried out in Slovenia and around the world. In our study, we confirmed the findings of other studies that organizational culture of hierarchy, which is characterized by control over the work of subordinate employees, was still present in a high proportion in health care organisations. Culture, which promotes the introduction of changes is the least present in Slovenian hospitals, while employees have the greatest desire for clan and hierarchy culture and adhocracy. A major performance indicator of any healthy organization is job satisfaction, which is statistically significantly positively associated with organizational cultures of clan, market and adhocracy. We did not find a statistically significant association with indicators of job satisfaction for the organizational culture of hierarchy. Satisfaction indicators were explained by the cooperation between employees, leadership, decision-making and autonomy.

Presented results provide many opportunities for further research. We suggest carrying out a survey at primary, secondary and tertiary levels of health care in Slovenia and abroad with a randomly selected representative sample of at least three occupational groups using mixed methods in order to increase the validity of the research. It would be reasonable to compare the results between different levels of health care as well as the employees of each occupational group in Slovenia and other countries. The overview of literature revealed that stress at work, abusing the power associated with position, absenteeism and fluctuation statistically significantly affect the dissatisfaction of employees at, so it would be reasonable to continue to explore these areas and compare them with international studies.

\section{Acknowledgement}

We would like to thank the health care and nursing management, and nursing employees and medical practitioners for participating in the study.

\section{Slovenian translation/Prevod $v$ slovenščino}

\section{Uvod}

Schein (1999) pravi, da $\mathrm{v}$ organizaciji določen tip organizacijske kulture vedno prevladuje, leta predstavlja način, kako zaposleni $\mathrm{v}$ organizaciji komunicirajo, rešujejo konflikte, timsko sodelujejo in se medsebojno povezujejo. Potrebno je razvijati organizacijsko kulturo, ki bo podpirala varno in kakovostno zdravstveno obravnavo pacienta (Alexander, et al., 2006; Alexander, et al., 2007; ReyesAlcázar, et al., 2009; Ledderer, 2010). V ta namen je potrebno razvijati gradnike organizacijske kulture, kot so vodenje, timsko delo, na dokazih podprta praksa, komunikacija (Sammer, et al., 2010).

Izvedena presečna študija je pokazala, da je organizacijska kultura statistično značilno povezana z ravnanjem vodij, le-to pa je statistično značilno povezano z zadovoljstvom (Tsai, 2011). Raziskava z randomiziranim vzorcem medicinskih sester je pokazala, da se lahko zadovoljstvo v $20 \%$ pojasni z avtentičnim načinom vodenja (Giallonardo, et al., 2010). V kanadski bolnišnici so na podlagi intervjujev ugotovili, da medicinske sestre nimajo priložnosti sodelovati $\mathrm{v}$ procesu sprejemanja odločitev in pri uvajanju sprememb. Medicinske sestre so povedale, da niso vključene $\mathrm{v}$ raziskovalni proces, čeprav je bila $\mathrm{v}$ času študija poudarjena na dokazih podprta praksa zdravstvene nege (Scott \& Pollock, 2008). Raziskava v bolnišnicah v Grčiji med 749 zaposlenimi različnih poklicnih skupin je pokazala hierarhično organiziranost, želeli so si več timskega sodelovanja (Bellou, 2007). Bosch in sodelavci (2011) so izvedli presečno študijo med 460 zdravstvenimi delavci na 37 bolniških oddelkih in 67 oddelkih $\mathrm{v}$ domu upokojencev. Ugotovili so, da v bolnišnici prevladuje organizacijska kultura hierarhije, sledi ji kultura skupine, medtem ko je v domu upokojencev največ kulture skupine, sledi ji hierarhija. Tako v bolnišnici kot $\mathrm{v}$ domu upokojencev je najmanj kulture trga in adhokracije.

V Združenih državah Amerike so ugotovili, da se indikatorji zadovoljstva zaposlenih lahko pojasnijo z organizacijsko kulturo. Za kulturo skupine je bila ocenjena pozitivna statistično značilna povezanost, za kulturi hierarhije in trga negativna statistično značilna povezanost, pri kulturi adhokracije ni bilo ocenjene statistično značilne povezanosti z indikatorji zadovoljstva. Med zdravniki prevladuje kultura skupine, sledijo ji trg, hiearhija in adhokracija (Zazzali, et al., 2007). Združenje ameriških medicinskih sester (American Nurses Association - ANA) je ustanovilo bazo indikatorjev kakovostne zdravstvene nege, eden izmed indikatorjev je zadovoljstvo zaposlenih. Zadovoljstvo zaposlenih je pomemben dejavnik, ki statistično značilno vpliva na fluktuacijo in absentizem zaposlenih ter kakovostno zdravstveno obravnavo pacientov (Taunton, et al., 2004). Odvisno je od motivov posameznikov, osnova za določitev indikatorjev zadovoljstva sta motivacijski teoriji po Maslowu in Herzbergu (Zangaro \& Soeken, 2005).

Lorber in Skela Savič (2012) sta v štirih slovenskih bolnišnicah identificirali štiri skupne indikatorje zadovoljstva zaposlenih v zdravstveni negi, in sicer motivacija, način vodenja, profesionalni razvoj ter sodelovanje in medosebni odnosi. Profesionalni razvoj ni neposredno povezan z zadovoljstvom, ampak je statistično značilno pozitivno povezan $\mathrm{z}$ avtonomijo medicinskih sester, le-ta pa vpliva na zadovoljstvo 
zaposlenih (Cummings, et al., 2008). Z avtonomijo, položajem na delovnem mestu, medosebnimi odnosi in plačo se lahko pojasni $50 \%$ variabilnosti zadovoljstva zaposlenih (Taunton, et al., 2004). Stres in izgorelost na delovnem mestu ter izmensko delo so statistično značilno negativno povezani z indikatorji zadovoljstva medicinskih sester (Kawada \& Otsuka, 2011). Pri zdravnikih so identificirali naslednje dejavnike zadovoljstva: avtonomija, medosebni odnosi med zaposlenimi, odnosi s pacienti, položaj na delovnem mestu, plača, osebni dohodek (Williams, et al., 2007).

\section{Namen in cilj}

Namen raziskave je bil prikazati značilnosti organizacijske kulture $\mathrm{v}$ splošnih bolnišnicah $\mathrm{v}$ Sloveniji in indikatorje zadovoljstva zaposlenih $\mathrm{v}$ dejavnosti medicine in zdravstvene nege. Cilj raziskave je bil raziskati tipe organizacijske kulture $\mathrm{v}$ splošnih bolnišnicah in oceniti primerjavo $\mathrm{z}$ drugimi raziskavami v Sloveniji in svetu. Preveriti smo želeli tudi pojasnjevalni model indikatorjev zadovoljstva zaposlenih.

\section{Hipoteze}

H1: Anketiranci z višjo stopnjo izobrazbe $\mathrm{v}$ večji meri ocenjujejo prisotnost organizacijske kulture skupine in adhokracije $\mathrm{v}$ delovnem okolju kot anketiranci z nižjo stopnjo izobrazbe.

H2: Indikatorje zadovoljstva zaposlenih v zdravstveni negi in medicini lahko pojasnimo $s$ timskim sodelovanjem, načinom vodenja in odločanja.

H3: Organizacijska kultura adhokracija statistično značilno pozitivno vpliva na indikatorje zadovoljstva.

\section{Metode}

Za izvedbo raziskave smo uporabili kvantitativni raziskovalni pristop ter deskriptivno metodo dela.

\section{Opis instrumenta}

Vprašalnik je bil sestavljen iz dveh vsebinskih sklopov, in sicer organizacijske kulture $\mathrm{v}$ zdravstvu in zadovoljstva zaposlenih na delovnem mestu. $\mathrm{Za}$ oba vsebinska sklopa smo uporabili vprašalnika, predhodno že testirana $\mathrm{v}$ zdravstvenih organizacijah. Na začetku vprašalnika smo spraševali po demografskih podatkih, in sicer splošnih podatkih (starost, spol, delovne izkušnje v zdravstveni negi/medicini), položaju zaposlenega na delovnem mestu, stopnji izobrazbe in področju dela zaposlenega (medicina/zdravstvena nega).

Za proučevanje organizacijske kulture smo uporabili vprašalnik Organization Culture Assessment Instrument (OCAI) po Cameron \& Quinn (1999), ki sta razdelila organizacijsko kulturo $v$ štiri tipe: hierarhija, skupina, trg in adhokracija. Organizacijski kulturi hierarhija in skupina sta usmerjeni navznoter, organizacijski kulturi trg in adhokracija pa navzven. Za organizacijski kulturi hierarhijo in trg je značilno stabilno okolje in centralno odločanje. Avtorja navajata, da je bila organizacijska kultura skupina značilna za japonska podjetja že v letih med 1960 in 1970. Zaposleni si delijo vrednote in cilje, glavne značilnosti niso pravila, ampak kohezija, predanost in spodbujanje profesionalnega razvoja. $\mathrm{Za}$ organizacijsko kulturo adhokracijo je značilno dinamično in ustvarjalno delovno okolje. Instrument ocenjuje šest ključnih dimenzij organizacijske kulture: prevladujoče značilnosti organizacije, vodenje $\mathrm{v}$ organizaciji, delo z ljudmi, organizacijsko povezanost, poudarjene strategije in kriterije za doseganje uspeha. V vsakem sklopu so štiri vprašanja, med katera so anketiranci razdelili skupno 100 točk, ki predstavljajo deleže strinjanja s posamezno trditvijo. Anketiranci so se do posamezne trditve opredelili za dve časovni obdobji: stanje danes in želja za prihodnost. Koeficient zanesljivosti (Cronbachov koeficient alfa) je za vseh 48 trditev v vprašalniku za ugotavljanje organizacijske kulture znašal 0,818 .

Uporabili smo vprašalnik iz doktorske disertacije »Dejavniki uspešnega izvajanja sprememb v slovenskem zdravstvu« (Skela Savič, 2007).

Za proučevanje indikatorjev zadovoljstva zaposlenih na delovnem mestu $\mathrm{v}$ dejavnosti medicine in zdravstvene nege smo uporabili merilni instrument Index of Work Satisfaction (IWS). IWS vključuje šest indikatorjev zadovoljstva $\mathrm{z}$ delom, sestavljen je iz 48 trditev, uporabljena je sedemstopenjska Likertova lestvica (Murrells, et al., 2009). Vprašalnik je bil oblikovan na podlagi metaanalize, testiran je bil v mnogih zdravstvenih organizacijah $\mathrm{v}$ Združenih državah Amerike in pokazal visoko zanesljivost pri ugotavljanju indikatorjev zadovoljstva med zaposlenimi v zdravstvu (Zangaro \& Soeken, 2005). V naši raziskavi smo uporabili 37 trditev iz omenjenega vprašalnika, trditve smo prevedli v slovenski jezik, uporabili smo petstopenjsko Likertovo lestvico, pri kateri je vrednost 1 pomenila, da se anketiranci s trditvijo sploh ne strinjajo, in 5, da se popolnoma strinjajo, vmesne ocene so ustrezale vrednostni lestvici. Koeficient zanesljivosti instrumenta (Cronbachov koeficient alfa) je bil 0,921.

\section{Opis vzorca}

Raziskavo smo izvedli v šestih splošnih bolnišnicah v Sloveniji, ki so dale soglasje za sodelovanje; sodelovali so zaposleni $\mathrm{v}$ dejavnosti zdravstvene nege in medicine. Uporabili smo nenaključni, kvotni vzorec. Odločili smo se za $30 \%$ vzorec anketirancev (Tabela 1). Med zaposlene $\mathrm{v}$ medicini smo razdelili nekoliko večji delež vprašalnikov, ker smo že pred izvedbo raziskave pričakovali manjšo odzivnost glede na zaposlene $\mathrm{v}$ zdravstveni negi. 
Tabela 1: Struktura vzorca

Table 1: Sample structure

\begin{tabular}{llllll}
\hline Področje dela & $\begin{array}{l}\text { Število } \\
\text { razdeljenih } \\
\text { vprašalnikov }(\boldsymbol{n})\end{array}$ & $\begin{array}{l}\text { Delež razdeljenih } \\
\text { vprašalnikov } \\
\text { glede na vse } \\
\text { zaposlene } \\
\text { sodelujočih } \\
\text { bolnišnicah }(\%)\end{array}$ & $\begin{array}{l}\text { Število vrnjenih } \\
\text { vprašalnikov }(\boldsymbol{n})\end{array}$ & $\begin{array}{l}\text { Delež vrnjenih } \\
\text { vprašalnikov (\%) }\end{array}$ & $\begin{array}{l}\text { Delež vrnjenih } \\
\text { vprašalnikov glede } \\
\text { na vse zaposlene } \\
\text { v sodelujočih } \\
\text { bolnišnicah }(\%)\end{array}$ \\
\hline Zdravstvena nega & 630 & 29,4 & 250 & 39,7 & 11,7 \\
\hline Medicina & 250 & 34,4 & 60 & 24 & 8,2 \\
\hline Skupno & 880 & 30,6 & 310 & 35,2 & 10,8 \\
\hline Legenda/Legend: $n-$ število/number; \%-odstotek/percentage & & &
\end{tabular}

Med poklicni skupini smo razdelili 880 vprašalnikov, vrnjenih smo prejeli 310, kar predstavlja 35,2\% odzivnost. Zaposlenim $\mathrm{v}$ medicini smo razdelili 250 vprašalnikov, vrnjenih smo jih prejeli 60 , kar predstavlja $24 \%$ odzivnost. Zaposlenim v zdravstveni negi smo razdelili 630 vprašalnikov, vrnjenih smo prejeli 250, kar predstavlja 39,7\% odzivnost. Vrnjeni vprašalniki predstavljajo $10,8 \%$ vzorec glede na vse zaposlene v zdravstveni negi in medicini v sodelujočih bolnišnicah.

Povprečna starost med anketiranci je bila 38,3 leta (37,2 pri medicinskih sestrah in 43,2 pri zdravnikih) in povprečna doba delovnih izkušenj v bolnišnici 16,3 let (16,4 pri medicinskih sestrah in 15,6 pri zdravnikih). Med anketiranci jih je bilo 48 (15,5\%) na vodilnem mestu, med medicinskimi sestrami je bilo vodij 30 (12\%), med zdravnikih 18 (30\%). Med anketiranci je bilo $58(18,7 \%)$ moških in 251 (81 \%) žensk, en $(0,3 \%)$ anketiranec ni odgovoril na vprašanje o spolu. Pri obeh poklicnih skupinah so prevladovale ženske (v $88 \%$ pri medicinskih sestrah in v 51,7\% pri zdravnikih). Medicinske sestre, ki so sodelovale $\mathrm{v}$ raziskavi, so imele srednješolsko izobrazbo (50\%), visokošolsko strokovno (41,2 \%), v manjših deležih pa tudi višješolsko izobrazbo (3,2 \%), strokovni magisterij $(3,2 \%)$, univerzitetno izobrazbo (1,2 \%), magisterij znanosti (1,2 \%). Med zdravniki, ki so sodelovali v raziskavi, jih je imelo največ doktorat znanosti $(41,7 \%)$, specializacijo (26,7 \%), univerzitetno izobrazbo (25\%), v manjšem deležu magisterij znanosti (6,6 \%).

\section{Opis poteka raziskave in obdelave podatkov}

$\mathrm{Za}$ sodelovanje $\mathrm{v}$ raziskavi smo poslali prošnje zdravstvenemu menedžmentu in menedžmentu zdravstvene nege $\mathrm{v}$ vseh deset splošnih bolnišnic $\mathrm{v}$ Sloveniji, z raziskavo se je soglašalo šest bolnišnic. $\mathrm{Na}$ podlagi soglasja je raziskava potekala od maja 2012 do februarja 2013. K vprašalnikom je bil priložen spremni dopis znavedbo namena in ciljev raziskave. Sodelovanje $\mathrm{v}$ raziskavi je bilo prostovoljno, zagotovljena je bila anonimnost, saj so bili podatki interpretirani le $\mathrm{v}$ sumarni obliki. Koordiniranje raziskave je potekalo preko telefona in elektronske pošte. $\mathrm{V}$ vsaki splošni bolnišnici je bila določena odgovorna oseba, ki je poskrbela za potek anketiranja, izpolnitev in vrnitev vprašalnikov po pošti. Za izpolnjevanje vprašalnika so anketiranci imeli štirinajst dni časa.

Podatki so bili obdelani s statističnim računalniškim programom SPSS 20.0 (SPSS, Chicago, IL, USA). Z neodvisnimi spremenljivkami (demografski podatki, organizacijska kultura) smo pojasnili odvisne spremenljivke (indikatorji zadovoljstva zaposlenih). Uporabili smo $t$-test za oceno aritmetične sredine, $t$-test za neodvisne vzorce, enosmerno analizo variance, korelacijsko, faktorsko in regresijsko analizo. $\mathrm{S} t$-testom za oceno aritmetične sredine smo ocenili povprečne vrednosti posameznih tipov organizacijske kulture. $S$ t-testom za neodvisne vzorce smo ugotavljali statistično značilne razlike med posameznimi tipi organizacijske kulture glede na poklicni skupini zdravstvena nega in medicina. $\mathrm{Z}$ enosmerno analizo variance smo ugotavljali statistično značilne razlike glede na stopnjo izobrazbe pri ocenjevanju organizacijske kulture. S korelacijsko analizo smo ugotavljali statistično značilno povezanost med posameznimi spremenljivkami. Uporabili smo Pearsonov koeficient korelacije. V nadaljevanju smo ocenili splošni faktorski model ter z metodo največjega verjetja in pravokotno rotacijo varimax pojasnili delež variance proučevanih spremenljivk s skupnimi faktorji (komunalitete). Odkrili smo skupne razsežnosti opazovanih spremenljivk in tako dobili vpogled $\mathrm{v}$ osnovno strukturo podatkov. Z manjšim številom latentnih spremenljivk, imenovanih faktorji, smo pojasnili zveze med opazovanimi spremenljivkami. $\mathrm{Z}$ regresijsko analizo smo ugotavljali, s katerimi neodvisnimi spremenljivkami lahko pojasnimo odvisno spremenljivko. Ocenili smo multivariatni linearni regresijski model. Statistično značilnost smo preverjali na ravni $5 \%$ tveganja $(p=0,05)$.

\section{Rezultati}

Z raziskavo smo ugotovili, da so prisotni vsi tipi organizacijske kulture po Cameron in Quinn (1999). Rezultati so prikazani v Tabeli 2.

$S$ t-testom za oceno aritmetične sredine smo ocenili, da je skupna največja povprečna vrednost med zaposlenimi $\mathrm{v}$ obeh poklicnih skupinah pri 
Tabela 2: Ocena organizacijske kulture

Table 2: Assessment of organizational culture

\begin{tabular}{|c|c|c|c|c|c|c|c|c|}
\hline \multirow{2}{*}{$\begin{array}{l}\text { Tip organizacijske } \\
\text { kulture }\end{array}$} & \multicolumn{2}{|c|}{ Skupno } & \multicolumn{2}{|c|}{ Medicina } & \multicolumn{2}{|c|}{ Zdravstvena nega } & \multicolumn{2}{|c|}{$\begin{array}{l}\text { Razlika med } \\
\text { skupinama }\end{array}$} \\
\hline & $\overline{\mathrm{X}}$ & $s$ & $\overline{\mathrm{x}}$ & $s$ & $\overline{\mathrm{X}}$ & $s$ & $F$ & $p$ \\
\hline \multirow{2}{*}{$\begin{array}{l}\text { HIERARHIJA } \\
\text { danes } \\
\text { želja za prihodnost }\end{array}$} & 27,57 & 19,56 & 19,93 & 23,28 & 29,4 & 18,13 & 1,71 & 0,191 \\
\hline & 22,63 & 21,7 & 23,41 & 32 & 22,44 & 18,46 & 18,7 & $<0,001$ \\
\hline \multirow{2}{*}{$\begin{array}{l}\text { SKUPINA } \\
\text { danes } \\
\text { želja za prihodnost }\end{array}$} & 22,37 & 16,5 & 28,31 & 28,6 & 22,39 & 15,16 & 18,69 & $<0,001$ \\
\hline & 32,58 & 21,1 & 34,83 & 35,9 & 35,64 & 19,97 & 1,06 & 0,302 \\
\hline \multirow{2}{*}{$\begin{array}{l}\text { TRG } \\
\text { danes } \\
\text { želja za prihodnost }\end{array}$} & 28,21 & 20,43 & 25,26 & 26,53 & 28,92 & 18,67 & 10,9 & 0,001 \\
\hline & 18,03 & 18,83 & 20,58 & 28,86 & 17,42 & 15,51 & 21,44 & $<0,001$ \\
\hline \multirow{2}{*}{$\begin{array}{l}\text { ADHOKRACIJA } \\
\text { danes } \\
\text { želja za prihodnost }\end{array}$} & 21,14 & 18,79 & 23,23 & 28,36 & 20,63 & 15,69 & 20,42 & $<0,001$ \\
\hline & 21,95 & 19,26 & 17,5 & 20,03 & 23,02 & 18,96 & 1,42 & 0,233 \\
\hline
\end{tabular}

Legenda/Legend: $\overline{\mathrm{X}}$ - povprečje/average; $s$ - standardni odklon/standard deviation; $p$ - statistično pomembna vrednost pri 0,05 ali manj/a statistically significant value in the 0.05 or less; $F$ - razlika med skupinami/difference between groups

organizacijski kulturi $\operatorname{trg}(\overline{\mathrm{x}}=28,21)$, sledi hierarhija $(\overline{\mathrm{x}}=27,57)$, nato $\mathrm{z}$ večjo razliko skupina $(\overline{\mathrm{x}}=22,37)$ in adhokracija $(\overline{\mathrm{x}}=21,14)$. Pri željah za prihodnost si zaposleni v največji meri želijo organizacijske kulture skupina $(\overline{\mathrm{x}}=32,58)$, nato med seboj bolj primerljivo sledijo hierarhija $(\overline{\mathrm{x}}=22,63)$, adhokracija $(\overline{\mathrm{x}}=21,95)$ in $\operatorname{trg}(\overline{\mathrm{x}}=18,03)$. $\mathrm{S}$ t-testom za neodvisne vzorce smo ocenili statistično značilne razlike glede na poklicni skupini pri ugotavljanju organizacijske kulture danes, in sicer pri organizacijskih kulturah adhokracija $(F=20,42, p<0,001)$, skupina $(F=18,69, p<0,001)$ in $\operatorname{trg}(F=10,9, p=0,001)$. Pri zdravnikih je v primerjavi $\mathrm{z}$ medicinskimi sestrami več organizacijskih kultur skupina in adhokracija, pri medicinskih sestrah pa več kulture trg. Pri željah za prihodnost so bile ugotovljene statistično značilne razlike pri organizacijski kulturi trg $(F=21,44, p<0,001)$ in hierarhija $(F=18,7, p<0,001)$, obeh omenjenih kultur si zdravniki želijo v večji meri kot medicinske sestre.

$\mathrm{Z}$ analizo variance (One-Way ANOVA) smo ugotavljali statistično značilne razlike organizacijske kulture glede na stopnjo izobrazbe. Posamezne stopnje izobrazbe smo združili v štiri kategorije: srednješolska, prva stopnja (višješolska, visokošolska strokovna), druga stopnja (univerzitetna, specializacija, strokovni magisterij) in tretja stopnja (magisterij znanosti in doktorat znanosti). Na podlagi Levenovega preskusa o enakosti varianc $v$ skupinah (Test of Homogeneity of Variances) smo s pomočjo F-preskusa oziroma preskusa Robust Welch ugotavljali, če se povprečne vrednosti med skupinami razlikujejo. Rezultati so pri organizacijski kulturi trg pokazali statistično značilne razlike glede na stopnjo izobrazbe $(p<0,000)$. Z najvišjo povprečno vrednostjo so trg ocenili zaposleni s prvo stopnjo izobrazbe $(\overline{\mathrm{x}}=28,2)$ in s srednješolsko izobrazbo $(\overline{\mathrm{x}}=27,1), \mathrm{z}$ nekoliko nižjo zaposleni $\mathrm{z}$ drugo stopnjo izobrazbe $(\overline{\mathrm{x}}=26,5)$, najmanj pa je te kulture med zaposlenimi s tretjo stopnjo izobrazbe $(\overline{\mathrm{x}}=17,44)$. Pri ostalih tipih organizacijske kulture nismo ugotovili statistično značilnih razlik glede na stopnjo izobrazbe. Pri željah za prihodnost smo ugotovili statistično značilne razlike glede na stopnjo izobrazbe pri organizacijski kulturi adhokracija $(p=0,005)$. Pri zaposlenih s prvo stopnjo izobrazbe je povprečna vrednost ocene najvišja $(\overline{\mathrm{x}}=25,15)$, sledi ocena zaposlenih s srednješolsko izobrazbo $(\overline{\mathrm{x}}=$ $20,94)$, tretjo $(\bar{x}=19,97)$ in drugo stopnjo izobrazbe $(\overline{\mathrm{x}}=18,42)$. Pri ostalih tipih organizacijske kulture med skupinami nismo ugotovili statistično značilnih razlik.

Pearsonov korelacijski koeficient je pokazal močno statistično značilno pozitivno povezanost med indikatorji zadovoljstva zaposlenih. Najmočnejšo statistično značilno pozitivno povezanost smo ugotovili med spoštovanjem druge poklicne skupine (medicina/zdravstvena nega) in trditvijo, da zaposleni cenijo delo druge poklicne skupine $(r=0,718, p<0,001)$, ter med priložnostjo sodelovanja pri odločitvah $\mathrm{v}$ zdravstvenem timu in odločitvah, ki se nanašajo na delo zaposlenega $(r=0,626, p<0,001)$. Samostojno sprejemanje odločitev je statistično značilno pozitivno povezano s priložnostjo sodelovanja pri odločitvah, ki se nanašajo na delo zaposlenega $(r=0,678, p<$ $0,001)$, in s priložnostjo sodelovanja pri odločitvah zdravstvenega tima $(r=0,521, p<0,001)$. Pearsonov korelacijski koeficient $(r>0,5)$ je pokazal statistično značilno pozitivno povezanost še pri naslednjih povezavah:

- podpora in prijaznost med sodelavci $(r=0,548$, $p<0,001)$;

- pomen zdravljenja in zdravstvene nege za kakovostno zdravje pacienta ter ceniti delo druge 
poklicne skupine $(r=0,558, p<0,001)$;

- pomen zdravljenja in zdravstvene nege za kakovostno zdravje pacienta ter spoštovati delo druge poklicne skupine $(r=0,520, p<0,001)$;

- trditev, da delo zaposlenemu omogoča, da pokaže svoje sposobnosti, in priložnost strokovnega usposabljanja $(r=0,506, p<0,001)$;

- sodelovanje $\mathrm{z}$ drugimi poklicnimi skupinami in zadovoljstvo $s$ sodelovanjem znotraj poklicne skupine $(r=0,504, p<0,001)$;

- samostojno sprejemanje odločitev in samostojno načrtovanje intervencij $\mathrm{v}$ okviru kompetenc $(r=$ $0,502, p=0,001)$.

$\mathrm{V}$ nadaljevanju prikazujemo skupne indikatorje zadovoljstva. S faktorsko analizo smo ugotovili, da lahko s petimi skupnimi faktorji pojasnimo $58,7 \%$ variabilnosti indikatorjev zadovoljstva zaposlenih. $\mathrm{Z}$ dobrim sodelovanjem lahko pojasnimo $26,1 \%$, z zadovoljstvom $\mathrm{z}$ odločanjem $16,7 \%$, z zadovoljstvom $\mathrm{z}$ vodenjem $10,3 \%$, z obremenjenostjo na delovnem mestu $7,5 \%$ in $\mathrm{z}$ avtonomijo $6,5 \%$ variabilnosti zadovoljstva zaposlenih. V Tabeli 3 so prikazane faktorske uteži s pravokotno rotacijo varimax, na podlagi katere je bila vrednost Kaiser-MeyerOlkinovega testa najvišja $(0,861)$, ta rotacija je $\mathrm{v}$ primerjavi s poševno rotacijo oblimin pokazala tudi manjšo bipolarnost. S skupnimi faktorji pojasnjene trditve, pri katerih je bil delež variabilnosti manjši od 0,5 , smo izločili iz nadaljnje analize.

$\mathrm{Z}$ regresijsko analizo smo ugotavljali odvisnost indikatorjev zadovoljstva od posameznih tipov organizacijske kulture. V odvisno spremenljivko "indikatorji zadovoljstva" smo združili faktorje, ki smo jih identificirali s pomočjo faktorske analize. $\mathrm{V}$ neodvisne spremenljivke »tipi organizacijske kulture» smo za vsak tip organizacijske kulture združili šest trditev iz vprašalnika, ki opisujejo posamezne tipe organizacijske kulture. Ocenili smo multivariatni linearni regresijski model. Neodvisne spremenljivke smo vključevali $\mathrm{v}$ regresijski model po principu dodajanja naprej (ang. forward selection). Pri tej metodi se neodvisne spremenljivke vključujejo $\mathrm{v}$ regresijski model po vrstnem redu, določenem $\mathrm{z}$ velikostjo njihovega vpliva na odvisno spremenljivko. Najprej je v model vključena neodvisna spremenljivka, ki najbolj vpliva na odvisno, nato naslednja, ki najbolj vpliva na odvisno spremenljivko, pod pogojem, da je prva spremenljivka že $\mathrm{v}$ modelu. $\mathrm{V}$ organizaciji so prisotni vsi tipi organizacijske kulture, vendar $\mathrm{v}$ različnih deležih (Schein, 1999), zato smo se odločili ugotoviti, katere kombinacije kultur najmočneje vplivajo na zadovoljstvo zaposlenih. $\mathrm{Na}$ podlagi vzorca zdravnikov in medicinskih sester v slovenskih splošnih bolnišnicah smo sprejeli sklep, da vsaj en tip organizacijske kulture statistično značilno vpliva na indikatorje zadovoljstva zaposlenih na delovnem mestu. Regresijski koeficienti so pokazali, da na indikatorje zadovoljstva zaposlenih statistično značilno pozitivno vplivajo naslednje kombinacije tipov organizacijskih kultur:

- organizacijska kultura adhokracija $(\beta=0,391, p<$ 0,001 ),

- organizacijski kulturi adhokracija $(\beta=0,377, p<$ $0,001)$ in $\operatorname{trg}(\beta=0,163, p=0,002)$,

- organizacijske kulture adhokracija $(\beta=0,318, p<$ $0,001), \operatorname{trg}(\beta=0,219, p<0,001)$ in skupina $(\beta=$ $0,161, p=0,006)$.

$\mathrm{Za}$ organizacijsko kulturo hiearhija je bilo

Tabela 3: Pravokotna rotacija faktorjev zadovoljstva zaposlenih

Table 3: Varimax rotation metod of job satisfaction

\begin{tabular}{|c|c|c|c|c|c|}
\hline \multirow[b]{2}{*}{ Trditve } & \multicolumn{4}{|c|}{ Faktorji } & \multirow[b]{2}{*}{5} \\
\hline & 1 & 2 & 3 & 4 & \\
\hline Zaposleni cenijo delo druge poklicne skupine. & 0,714 & I & I & I & I \\
\hline Zadovoljstvo z delom druge poklicne skupine. & 0,666 & 1 & I & 1 & I \\
\hline Zaposleni spoštujejo delo druge poklicne skupine. & 0,646 & 1 & 1 & 1 & 1 \\
\hline $\begin{array}{l}\text { Priložnost sodelovati pri odločitvah, ki se nanašajo na } \\
\text { delo zaposlenega. }\end{array}$ & / & 0,858 & l & / & l \\
\hline Samostojno sprejemanje odločitev v okviru kompetenc. & l & 0,682 & I & 1 & I \\
\hline Priložnost sodelovati pri odločitvah v zdravstvenem timu. & I & 0,642 & l & I & I \\
\hline Za dobro opravljeno delo zaposleni prejmejo nagrado. & I & 1 & 0,760 & 1 & l \\
\hline Zaposleni pri delu opravljajo le rutinske zadeve. & I & / & 0,544 & I & l \\
\hline Vodja nadzira delo zaposlenih več, kot je potrebno. & I & / & 0,545 & I & l \\
\hline $\begin{array}{l}\text { Zaposleni bi svoje delo bolj kakovostno opravljali, če bi bili na delovnem } \\
\text { mestu manj obremenjeni. }\end{array}$ & I & / & / & 0,894 & l \\
\hline Delo z dokumentacijo zaposlenim vzame veliko časa. & I & I & l & 0,471 & I \\
\hline $\begin{array}{l}\text { Zaposleni bi pacientom nudili bolj kakovostno zdravstveno oskrbo, če bi } \\
\text { imeli več časa za vsakega pacienta. }\end{array}$ & I & / & / & 0,469 & l \\
\hline $\begin{array}{l}\text { Zaposleni imajo na delovnem mestu dovolj avtonomije za samostojno } \\
\text { odločanje o svojem delu. }\end{array}$ & l & / & I & l & 0,736 \\
\hline Vodja pohvali zaposlene za dobro opravljeno delo. & I & l & 1 & 1 & 0,513 \\
\hline
\end{tabular}


ugotovljeno, da statistično značilno ne vpliva na zadovoljstvo zaposlenih $(p=0,490)$. V Tabeli 4 je prikazan multivariatni linearni regresijski model za indikatorje zadovoljstva zaposlenih na delovnem mestu. kultura trga, sledijo kultura hierarhije, skupine in adhokracije. Med obema poklicnima skupinama obstajajo statistično značilne razlike pri ugotavljanju organizacijske kulture danes, in sicer pri organizacijskih

Tabela 4: Multivariatni linearni regresijski model za indikatorje zadovoljstva zaposlenih

Table 4: The multivariate linear regression model for indicators of job satisfaction

\begin{tabular}{llllll}
\hline Model & $\boldsymbol{R}$ & $\boldsymbol{R}^{2}$ & popravljeni $\boldsymbol{R}^{2}$ & $\boldsymbol{F}$ & $\boldsymbol{p}$ \\
\hline Organizacijska kultura adhokracija & 0,391 & 0,153 & 0,150 & 55,73 & $<0,001$ \\
\hline Organizacijski kulturi adhokracija in trg & 0,424 & 0,180 & 0,174 & 33,64 & $<0,001$ \\
\hline Organizacijske kulture adhokracija, trg in skupina & 0,447 & 0,200 & 0,192 & 25,44 & $<0,001$ \\
\hline
\end{tabular}

Legenda/Legend: $R$ - korelacijski koeficient/the correlation coefficient; $R^{2}$ - determinacijski koeficient/ the coefficient of

determination; popravljeni R2 - popravljeni determinacijski koeficient/ the adjusted coefficient of determination; $p$ - statistična značilnost pri 0,05 ali manj/statistically significant at 0.05 or less

$\mathrm{Na}$ podlagi ocene korelacijskega koeficienta smo ugotovili, da je povezanost med organizacijsko kulturo in indikatorji zadovoljstva zaposlenih pozitivna in srednje močna. Pri kombinaciji treh organizacijskih kultur, in sicer adhokracija, trg in skupina, je povezava najmočnejša $(R=0,447)$. Ocenjeni determinacijski koeficient je pokazal, da lahko $15 \%$ variance indikatorjev zadovoljstva zaposlenih pojasnimo $\mathrm{z}$ organizacijsko kulturo adhokracija, $18 \%$ skombinacijo organizacijskih kultur adhokracija in trg ter $20 \% \mathrm{~s}$ kombinacijo organizacijskih kultur adhokracija, trg in skupina.

\section{Diskusija}

$\mathrm{V}$ raziskavi smo na podlagi vzorčnih podatkov prikazali indikatorje, s katerimi lahko pojasnimo zadovoljstvo zaposlenih na delovnem mestu med zdravniki in medicinskimi sestrami $\mathrm{v}$ splošnih bolnišnicah v Sloveniji. Proučevali smo povezave med neodvisnimi in odvisnimi spremenljivkami. Identificirali smo naslednje indikatorje zadovoljstva: dobro sodelovanje, zadovoljstvo $\mathrm{z}$ vodenjem, zadovoljstvo $\mathrm{z}$ odločanjem, obremenjenost na delovnem mestu in avtonomija na delovnem mestu, medtem ko so $\mathrm{v}$ bolnišnici $\mathrm{v}$ Atlanti indikatorje zadovoljstva medicinskih sester pojasnili $\mathrm{z}$ vodenjem, sodelovanjem in podporo med zaposlenimi, sposobnostjo za menedžeriranje (Wade, et al., 2008). Do podobnih ugotovitev so prišli tudi Wang in sodelavci (2012), ki indikatorje zadovoljstva pojasnjujejo $\mathrm{z}$ osebnim dohodkom in nagradami, medpoklicnim sodelovanjem, profesionalnim razvojem, avtonomijo. Korelacijska analiza nam je pokazala šibko statistično značilno pozitivno povezanost med demografskimi dejavniki in indikatorji zadovoljstva zaposlenih, do podobnih ugotovitev so prišli tudi Carmeli (2005), Wade s sodelavci (2008), Tourangeau s sodelavci (2010) in Pavlakis s sodelavci (2011).

V naši raziskavi smo ocenili, da jev slovenskih splošnih bolnišnicah $\mathrm{v}$ največji meri prisotna organizacijska kulturah adhokracija, skupina in trg. Pri zdravnikih sta bolj prisotni kulturi skupina in adhokracija, pri medicinskih sestrah pa trg. Golob (2006) je prišla do podobnih ugotovitev: v Domu starejših občanov Novo mesto prav tako prevladuje kultura trga, medtem ko v Splošni bolnišnici Celje prevladuje kultura skupine (Kragelj, 2010). Medicinske sestre ocenjujejo, da prevladuje kultura trga in hierarhije, najmanj pa je med zaposlenimi prisotna kultura skupine, najnižje je bila ocenjena trditev glede možnosti profesionalnega razvoja zaposlenih (Tsai, 2011). Zaposleni $\mathrm{v}$ naši raziskavi si v največji meri želijo organizacijske kulture skupine in manj hierarhije, adhokracije in trga. Med obema poklicnima skupinama obstajajo statistično značilne razlike glede želene organizacijske kulture v prihodnosti, in sicer pri organizacijski kulturi trg in hierarhija. Obeh kultur si zdravniki želijo več kot medicinske sestre. V Splošni bolnišnici Celje (Kragelj, 2010) in kanadski bolnišnici (Williams, et al., 2007) pa si zaposleni želijo več kulture adhokracije.

Starost anketirancev in število let zaposlitve nimata pomembnega vpliva na tip organizacijske kulture, medtem ko ima stopnja dosežene izobrazbe statistično značilen vpliv na kulturo adhokracije in kulturo hierarhije (Skela Savič, 2006). Carmeli (2005) ni ugotovil statistično značilne povezanosti med demografskimi podatki in tipi organizacijske kulture, medtem ko smo $\mathrm{v}$ slovenskih bolnišnicah ugotovili šibko statistično značilno pozitivno povezanost med demografskimi dejavniki (starost, delovne izkušnje, položaj na delovnem mestu, stopnja izobrazbe) in organizacijsko kulturo. $\mathrm{Z}$ enosmerno analizo variance smo ugotovili statistično značilne razlike med posameznimi stopnjami izobrazbe samo pri organizacijski kulturi trg. Najnižjo povprečno vrednost prisotne kulture $\mathrm{v}$ slovenskih bolnišnicah smo ocenili pri zaposlenih s tretjo stopnjo izobrazbe. Skela Savič (2006) je ugotovila, da višja kot je stopnja dosežene izobrazbe pri anketirancih, le-ti bolj ocenjujejo prisotnost kulture hierarhije in manj kulture adhokracije v njihovem delovnem okolju. Pri zdravstveni negi je bilo ugotovljeno, da višja kot 
je stopnja izobrazbe, manj je organizacijska kultura $\mathrm{v}$ delovnem okolju ocenjena kot inovativna (Skela Savič, 2006). Pri željah za prihodnost so rezultati naše raziskave $\mathrm{v}$ slovenskih splošnih bolnišnicah pokazali statistično značilne razlike med skupinami pri organizacijski kulturi adhokracije. Omenjene kulture si najbolj želijo zaposleni s prvo stopnjo izobrazbe, najmanj pa zaposleni z drugo stopnjo izobrazbe.

Organizacijska kultura je statistično značilno pozitivno povezana $\mathrm{z}$ indikatorji zadovoljstva zaposlenih na delovnem mestu, vendar smo ugotovili, da so korelacije šibke. Do podobnih ugotovitev so prišli tudi Jacobs \& Roodt (2008) in Tsai (2011). Indikatorji zadovoljstva zaposlenih so statistično značilno pozitivno povezani $\mathrm{z}$ organizacijskima kulturama skupina (Williams, et al., 2007; Park \& Hyun, 2009) in trg, medtem ko pri kulturah hierarhija in adhokracija ni bilo ugotovljene statistično značilne povezave $\mathrm{z}$ indikatorji zadovoljstva (Park \& Hyun, 2009). V naši raziskavi je regresijska analiza pokazala, da na indikatorje zadovoljstva zaposlenih najbolj statistično značilno pozitivno vpliva prisotnost treh tipov organizacijskih kultur, in sicer adhokracije, trga in skupine.

\section{Omejitve raziskave}

Metodološke omejitve raziskave so bile, da je bila raziskava izvedena $\mathrm{v}$ šestih od desetih splošnih bolnišnic, sodelovali so zaposleni $\mathrm{v}$ dejavnosti medicine in dejavnosti zdravstvene nege, pri zaposlenih $\mathrm{v}$ dejavnosti medicine je bila nižja odzivnost kot pri zaposlenih $\mathrm{v}$ zdravstveni negi. Rezultatov raziskave ne moremo posploševati, ker je bil uporabljen nenaključni, kvotni vzorec, pri katerem ne moremo ugotoviti kakovosti vzorčne ocene. Uporabili smo le kvantitativni raziskovalni pristop, metodo anketiranja. Schein (1999) pravi, da je pri ocenjevanju organizacijske kulture potrebno uporabiti tudi druge metode raziskovanja (intervju, metoda opazovanja, triangulacija ipd.). Rezultati analize organizacijske kulture so pokazali visoke vrednosti standardnih odklonov, kar pomeni veliko variabilnost podatkov, pri zdravnikih je bila le-ta večja kot pri medicinskih sestrah. Posamezne trditve v vprašalniku so bile ocenjene od 0 do 100 .

\section{Zaključek}

Dosežena sta bila namen in cilj raziskave, ocenjeni so bili indikatorji zadovoljstva zaposlenih in značilnosti organizacijske kulture $\mathrm{v}$ splošnih bolnišnicah $\mathrm{v}$ Sloveniji ter primerjani $\mathrm{z}$ drugimi izvedenimi raziskavami $\mathrm{v}$ Sloveniji in svetu. $\mathrm{V}$ naši raziskavi smo potrdili spoznanja že izvedenih raziskav, da je $\mathrm{v}$ zdravstvenih organizacijah še vedno $\mathrm{v}$ visokem deležu prisotna organizacijska kultura hierarhija, za katero je značilen nadzor nad opravljenim delom podrejenih zaposlenih. $\mathrm{V}$ slovenskih bolnišnicah je najmanj prisotna kultura, ki spodbuja uvajanje sprememb, zaposleni si v večji meri želijo kulturo skupine in hierarhije kot adhokracije. Pomemben kazalec uspešnosti vsake zdravstvene organizacije je zadovoljstvo zaposlenih, le-to je statistično značilno pozitivno povezano s kombinacijo organizacijskih kultur skupina, trg in adhokracija. Za organizacijsko kulturo hierarhija nismo ugotovili statistično značilne povezanosti $\mathrm{z}$ indikatorji zadovoljstva zaposlenih. Indikatorje zadovoljstva smo pojasnili z medsebojnim sodelovanjem med zaposlenimi, vodenjem, odločanjem in avtonomijo.

Prikazani rezultati dajejo veliko možnosti za nadaljnje raziskovanje. Predlagamo izvedbo raziskave na primarnem, sekundarnem in terciarnem nivoju zdravstvenega varstva $\mathrm{v}$ Sloveniji in tujini $\mathrm{z}$ naključno izbranim reprezentativnim vzorcem vsaj treh poklicnih skupin ter uporabo mešanih metod raziskovanja, s katerimi bi povečali veljavnost raziskave. Smiselno bi bilo primerjati rezultate med posameznimi nivoji zdravstvenega varstva kot tudi med zaposlenimi posameznih poklicnih skupin v Sloveniji in v državah po svetu. V pregledu literature smo zasledili, da stres na delovnem mestu, izkoriščanje moči položaja, absentizem in fluktuacija statistično značilno vplivajo na nezadovoljstvo zaposlenih na delovnem mestu, zato bi bilo $\mathrm{v}$ prihodnje smiselno raziskati še ta področja in jih primerjati z raziskavami v svetu.

\section{Zahvala}

Zdravstvenemu menedžmentu in menedžmentu zdravstvene nege ter zaposlenim $\mathrm{v}$ zdravstveni negi in medicini se zahvaljujemo za sodelovanje v raziskavi.

\section{Literature/Literatura}

Alexander, J.A., Weiner, B.J., Shortell, S.M. \& Baker, L.C., 2007. Does quality improvement implementation affect hospital quality of care? Research and Perspectives on Healthcare, 85 (2), pp. 11-20.

Alexander, J.A., Weiner, B.J., Shortell, S.M., Baker, L.C. \& Becker, M.P., 2006. The role of organizational infrastructure in implementation of hospitals' quality improvement. Research and Perspectives on Healthcare, 84(1), pp. 11-19.

Bellou, V., 2007. Achieving long-term customer satisfaction through organizational culture. Managing Service Quality, 17(5), pp. 510-522.

http://dx.doi.org/10.1108/09604520710817334

Bosch, M., Halfens, R.J.G., van der Weijden, T., Wensing, M., Akkermans, R. \& Grol, R., 2011. Organizational culture, team climate and quality management in an important patient safety issue: nosocomial pressure ulcers. Worldviews on Evidence- 
Based Nursing, 8 (1), pp. 4-14. http://dx.doi.org/10.1111/j.1741-6787.2010.00187.x PMid:20367807

Cameron, S.K. \& Quinn, R.E., 1999. Diagnosing and changing organizational culture: based on the competing values framework. San Francisco (CA): Addison-Wesley, pp. 12, 24-67.

Carmeli, A., 2005. The relationship between organizational culture and withdrawal intentions and behavior. International Journal of Manpower, 26 (2), pp. 177-195. http://dx.doi.org/10.1108/01437720510597667

Cummings, G.G., Olson, K., Hayduk, L., Bakker, D., Fitch, M., Green, E., et al., 2008. The relationship between nursing leadership and nurses' job satisfaction in Canadian oncology work environments. Journal of Nursing Management, 16 (5), pp. 508-518.

http://dx.doi.org/10.1111/j.1365-2834.2008.00897.x PMid:18558921

Giallonardo, L.M., Wong, C.A. \& Iwasiw, C.L., 2010. Authentic leadership of preceptors: predictor of new graduate nurses' work engagement and job satisfaction. Journal of Nursing Management, 18, pp. 993-1003.

http://dx.doi.org/10.1111/j.1365-2834.2010.01126.x

PMid:21073571

Golob, M., 2006. Organizacijska kultura v zavodu Dom starejših občanov Novo mesto: diplomsko delo. Ljubljana: Univerza v Ljubljani, Ekonomska fakulteta, pp. 26-27.

Jacobs, E. \& Roodt, G., 2008. Organizational culture of hospitals to predict turnover intentions of professional nurses. Health $\mathrm{Sa}$ Gesondheid, 13 (1), pp. 63-78.

http://dx.doi.org/10.4102/hsag.v13i1.258

Kawada, T. \& Otsuka, T., 2011. Relationship between job stress, occupational position and job satisfaction using a brief job stress questionnaire. Work, 40 (4), pp. 393-399.

PMid:22130057

Kragelj, J., 2010. Organizacijska kultura zaposlenih v zdravstveni negi $v$ bolnišnici: magistrska naloga. Koper: Univerza na Primorskem, Fakulteta za management Koper, pp. 31-35, 63. Available at: http://www.ediplome.fm-kp.si/Kragelj Jozica 20100922.pdf [25. 5. 2014].

Ledderer, L., 2010. Bringing about change in patient-centred preventive care. International Journal of Public Sector Management, 23 (4), pp. 403-412.

http://dx.doi.org/10.1108/09513551011047297

Lorber, M. \& Skela Savič, B., 2012. Job satisfaction of nurses and identifying factors of job satisfaction in Slovenian Hospitals. Croation Medical Journal, 53, pp. 263-270.

http://dx.doi.org/10.3325/cmj.2012.53.263

PMid:22661140; PMCid:PMC3368291
Murrells, T., Robinson, S. \& Griffiths., P., 2009. Nurses' job satisfaction in their early career: is it the same for all branches of nursing? Journal of Nursing Management, 17 (1), pp. 120 - 134. http://dx.doi.org/10.1111/j.1365-2834.2008.00854.x PMid:19166530

Park, J.S. \& Hyun, K.T., 2009. Do types of organizational culture matter in nurse job satisfaction and turnover intention? Leadership in Health Services, 22 (1), pp. 20-38. http://dx.doi.org/10.1108/17511870910928001

Pavlakis, A., Kaitelidou, D., Theodorou, M., Galanis, P., Sourtzi, P. \& Siskou, O., 2011. Conflict management in public hospitals: the Cyprus case. International Nursing Review, 58 (2), pp. 242248.

http://dx.doi.org/10.1111/j.1466-7657.2011.00880.x

PMid:21554299

Reyes-Alcázar, V., Sotillos-González, B., Torres-Olivera, A., 2009. Organizational value of healthcare quality awards in Andalusia. Leadership and Organization Development Journal, 30(5), pp. 475-487.

http://dx.doi.org/10.1108/01437730910968723

Sammer, C.E., Lykens, K., Singh, K.P., Mains, D.A. \& Lackan, N.A., 2010. What is patient safety culture? A review of the literature. Journal of Nursing Scholarship, 42(2), pp. 156-165. http://dx.doi.org/10.1111/j.1547-5069.2009.01330.x

PMid:20618600

Schein, E.H., 1999. The Corporate Culture Survival Guide: sense and nonsense about culture change. San Francisco (CA): JosseyBass Publishers, p. 21.

Scott, S.D. \& Pollock, C., 2008. The role of nursing unit culture in shaping research utilization behaviors. Research in Nursing \& Health, 31, pp. 298-309.

http://dx.doi.org/10.1002/nur.20264

PMid:18231975

Skela Savič, B., 2006. Organizacijska kultura in uvajanje sprememb $\mathrm{v}$ slovenskih bolnišnicah: subkulture in mesto zdravstvene nege? Obzornik zdravstvene nege, 40(4), pp. 187-196.

Skela Savič, B., 2007. Dejavniki uspešnega izvajanja sprememb $v$ slovenskem zdravstvu: doktorska disertacija. Kranj: Univerza v Mariboru, Fakulteta za organizacijske vede Kranj, pp. 38-40.

Taunton, R.L., Bott, M.J., Koehn, M.L., Miller, P., Rindner, E., Pace, K., et al., 2004. The NDNQI-adapted index of work satisfaction. Journal of Nursing Measurement, 12(2), pp. 101122.

http://dx.doi.org/10.1891/jnum.2004.12.2.101

PMid:16092709

Tourangeau, A., Cranley, L., Spence Laschinger, H.K. \& Pachis, J., 2010. Relationships among leadership practices, work environments, staff communication and outcomes in long-term 
care. Journal of Nursing Management, 18(8), pp. 1060-1072. http://dx.doi.org/10.1111/j.1365-2834.2010.01125.x

PMid:21073577

Tsai, Y., 2011. Relationship between organizational culture, leadership behaviour and job satisfaction. Health Services Research, 11(4), pp. 1-9.

Wade, G.H., Osgood, B., Avino, K., Bucher, G., Bucher, L., Foraker, T., et al., 2008. Influence of organizational characteristics and caring attributes of managers on nurses's job enjoyment. Journal of Advanced Nursing, 64(4), pp. 344-353. http://dx.doi.org/10.1111/j.1365-2648.2008.04775.x PMid:18990113

Wang, X., Chontawan, R. \& Nantsupawat, R., 2012. Transformational leadership: effect on the job satisfaction of Registered Nurses in a hospital in China. Journal of Advanced Nursing, 68(2), pp. 444-451.

http://dx.doi.org/10.1111/j.1365-2648.2011.05762.x

PMid:21771039

Cite as/Citirajte kot:

Skinder Savić, K. \& Skela-Savič, B. 2014. Organizational culture in general hospitals and its relationship with job satisfaction. Obzornik zdravstvene nege, 48(2), 88-103. http://dx.doi.org/10.14528/snr.2014.48.2.20
Williams, M.L., McDaniel M.A. \&. Ford, L.R., 2007. Understanding multiple dimensions of compensation satisfaction. Journal of Business and Psychology, 21 (3), pp. 429-459.

http://dx.doi.org/10.1007/s10869-006-9036-3

Zangaro, G.A., \& Soeken, K.L., 2005. Meta-analysis of the reliability and validity of part b of the index of work satisfaction across studies. Joumal of Nursing Measurement, 13(1), pp. 7-22. http://dx.doi.org/10.1891/jnum.2005.13.1.7

PMid:16315567

Zazzali, J.L., Alexander, J.A., Shortell, S.M. \&. Burns, L.R., 2007. Organizational culture and physician satisfaction with dimensions of group practice. Health Services Research, 42 (3), pp. 1150-1176.

PMid:17489908; PMCid:PMC1955261 http://dx.doi.org/10.1111/j.1475-6773.2006.00648.x 